\title{
Changes in Indian Summer Monsoon Using Neodymium (Nd) Isotopes in the Andaman Sea During the Last 24,000 years
}

\author{
Harunur Rashid ${ }^{1,2} \cdot$ Alexandra T. Gourlan $^{3} \cdot$ Brittany Marche $^{2} \cdot$ Kaylyn Sheppard $^{2} \cdot$ Nabil Khélifi $^{4}$
}

Received: 26 April 2019 / Accepted: 18 June 2019 / Published online: 27 June 2019

(c) The Author(s) 2019

\begin{abstract}
Dramatic changes from a cold and dry last glacial to a warm and wet Holocene period intensified the Indian summer monsoon (ISM), resulting in vigorous hydrology and increased terrestrial erosion. Here we present seawater neodymium (Nd) data (expressed in $\varepsilon_{\mathrm{Nd}}$ ) from Andaman Sea sediments to assess past changes in the ISM and the related impact of IrrawaddySalween and Sittoung (ISS) river discharge into the Andaman Sea in the northeastern Indian Ocean. Four major isotopic changes were identified: (1) a gradual increase in $\varepsilon_{\mathrm{Nd}}$ toward a more radiogenic signature during the Last Glacial Maximum (22-18 ka), suggesting a gradual decrease in the ISS discharge; (2) a relatively stable radiogenic seawater $\varepsilon_{\mathrm{Nd}}$ between 17.2 and $8.8 \mathrm{ka}$, perhaps related to a stable reduced outflow; (3) a rapid transition to less radiogenic $\varepsilon_{\mathrm{Nd}}$ signature after $8.8 \mathrm{ka}$, reflecting a very wet early-mid-Holocene with the highest discharge; and (4) a decrease in $\varepsilon_{\mathrm{Nd}}$ signal stability in the mid-late Holocene. Taking into account the contribution of the ISS rivers to the Andaman Sea $\varepsilon_{\mathrm{Nd}}$ signature that changes proportionally with the strengthening (less radiogenic $\varepsilon_{\mathrm{Nd}}$ ) or weakening (more radiogenic $\varepsilon_{\mathrm{Nd}}$ ) of the ISM, we propose a binary model mixing between the Salween and Irrawaddy rivers to explain the $\varepsilon_{\mathrm{Nd}}$ variability in Andaman Sea sediments. We hypothesize that the Irrawaddy river mainly contributed detrital sediment to the northeastern Andaman Sea for the past $24 \mathrm{ka}$. Our $\varepsilon_{\mathrm{Nd}}$ data shed new light on the regional changes in Indo-Asian monsoon systems when compared with the existing Indian and Chinese paleo-proxy records.
\end{abstract}

Keywords Nd isotopes · Continental erosion · Indian summer monsoon · Andaman Sea · Deglacial climate

\section{Introduction}

The Indian summer monsoon (ISM) is a dynamic climate system that brings enormous changes in the local hydrological cycle during the summer (Cane 2010). ISM is the product

Electronic supplementary material The online version of this article (https://doi.org/10.1007/s41748-019-00105-0) contains supplementary material, which is available to authorized users.

Harunur Rashid

Harunurbhola@gmail.com

1 College of Marine Sciences, Shanghai Ocean University, Shanghai, China

2 Earth and Environmental Sciences, Memorial University of Newfoundland, 20 University Drive, Corner Brook, NL, Canada

3 Université Grenoble Alpes, ISTerre, CS 40700, 38058 Grenoble Cedex 9, France

4 GEOMAR Helmholtz Centre for Ocean Research Kiel, Wischhofstraße 1-3, 24148 Kiel, Germany of a pressure difference between the Tibetan Plateau and the tropical Indian Ocean resulting from tropospheric heating. This seasonal low atmospheric pressure at the Tibetan Plateau relative to high pressure over the cooler Indian Ocean sets the stage for cyclonic summer monsoon wind patterns (Webster et al. 1998). Evaporation from the tropical Indian Ocean adds moisture, and latent heat intensifies the ISM.

On annual to decadal timescales, the ISM intensity is influenced by changes in internal boundary conditions such as tropical Indian Ocean sea-surface temperature (Webster et al. 1998), Eurasian snow cover (Barnett et al. 1988), and migration of the Intertropical Convergence Zone (ITCZ). About $80 \%$ of the monsoonal precipitation falls on the Ganga-Brahmaputra-Meghna (GBM) catchments (Hasan et al. 2014) and Irrawaddy-Salween-Sittoung (ISS) rivers (Fig. 1), draining eastern Himalaya covering China, most of Myanmar, and western Thailand (Robinson et al. 2014). As a result, high discharge into the Bay of Bengal and Andaman Sea (Murata et al. 2008) during the summer is a direct determinant of sea-surface conditions. On average, $\sim 1270 \mathrm{~km}^{3} /$ 


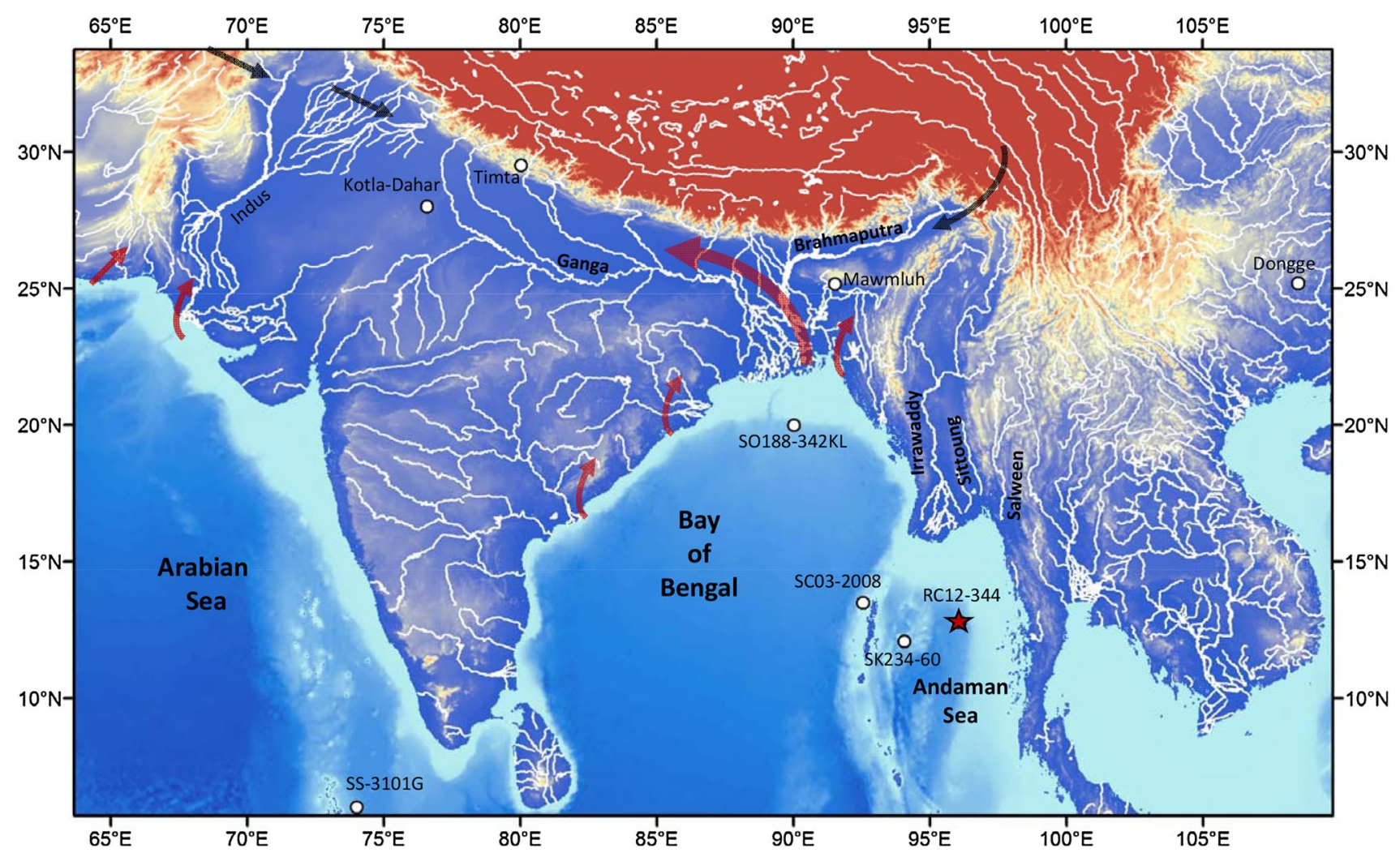

Fig. 1 Location of past Indian summer monsoon (ISM) proxy records used in the study as well as the Indus-Ganga-Brahmaputra-Meghna and Irrawaddy-Salween-Sittoung rivers and their numerous tributar- ies and distributaries. Red and black arrows depict the directions of the wind during the summer and winter, respectively. Star denotes the location of Andaman Sea core RC12-344

other pertinent information about the GBM and ISS rivers. These riverine discharges and sediment loads, hemipelagic and pelagic sediments deposited in the Andaman Sea are potential archives to reconstruct the past ISM changes and ensuing erosional history of most of Myanmar and eastern Himalaya.

Table 1 Drainage area, discharge, sediment yield, $\varepsilon_{\mathrm{Nd}}$ of river sediments and references related to the principal rivers in the northeastern Indian Ocean

\begin{tabular}{llllll}
\hline River name & $\begin{array}{l}\text { Drainage } \\
\text { area }\left(10^{6}\right. \\
\left.\mathrm{km}^{2}\right)\end{array}$ & Discharge $\left(\mathrm{km}^{3} / \mathrm{yr}\right)$ & $\begin{array}{l}\text { Sediment } \\
\text { yield (MT/ } \\
\mathrm{yr})\end{array}$ & $\varepsilon_{\mathrm{Nd}}$ particulate & References \\
\hline Irrawaddy & 0.413 & $440 \pm 49$ & $364 \pm 60$ & -10.7 to -8.3 & $\begin{array}{c}\text { Allen et al. (2008), Bender (1983), Chapman et al. (2015), Colin } \\
\text { et al. (1999), Robinson et al. (2007) }\end{array}$ \\
Salween & 0.272 & 211 & 180 & -18.1 to -13.6 & $\begin{array}{l}\text { Awasthi et al. (2014), Bender (1983), Chapman et al. (2015), } \\
\text { Robinson et al. (2007) } \\
\text { Robinson et al. (2007) }\end{array}$ \\
$\begin{array}{l}\text { Sittoung } \\
\text { GBM }\end{array}$ & 0.01452 & 43 & $27-36$ & 1060 & -18.2 to $-13.6 \begin{array}{l}\text { Milliman and Meade (1983), Milliman and Syvitski ( 1992), Tri- } \\
\text { pathy et al. (2011), Milliman and Farnsworth (2011), Lupker } \\
\text { et al. (2013) }\end{array}$ \\
\hline
\end{tabular}




\section{Application of Neodymium (Nd) Isotopes in the Northern Tropical Indian Ocean}

Marine sediments provide a record of past terrestrial and erosional history and accompanying changes in the seasurface conditions and ocean circulation. $\mathrm{Nd}$ isotopes have become a prominent proxy in reconstructing past changes in weathering and erosion and seawater (Frank 2002; Ahmad et al. 2005; Gourlan et al. 2010), in which the isotopic ratios are expressed in the typical $\varepsilon_{\mathrm{Nd}}$ notation, where

$$
\varepsilon_{\mathrm{Nd}}=\left[\frac{\left({ }^{143} \mathrm{Nd} /{ }^{144} \mathrm{Nd}\right) \text { sample }-\left({ }^{143} \mathrm{Nd} /{ }^{144} \mathrm{Nd}\right) \text { standard }}{\left({ }^{143} \mathrm{Nd} /{ }^{144} \mathrm{Nd}\right) \text { standard }}\right] \times 10^{4}
$$

The $\varepsilon_{\mathrm{Nd}}$ proxy is sensitive to precipitation on land because $\mathrm{Nd}$ is added to the oceans by weathering of terrestrial rocks and sediments. It is unlikely that the isotopic character of $\mathrm{Nd}$ would be significantly modified during chemical weathering (Borg and Banner 1996) or via grain-size sorting during transport (Lupker et al. 2013). Differences in age and composition of rocks surrounding each ocean give distinct $\varepsilon_{\mathrm{Nd}}$ signatures. Hence, each water mass has a characteristic $\varepsilon_{\mathrm{Nd}}$ signature, enabling it to be used as a proxy for changes in the circulation. The residence time of $\mathrm{Nd}(\leq 1000$ years) is shorter than that of the mixing time of the global ocean, and its isotopic distribution in each ocean reflects contributions from local sources (Jeandel 1993; Tachikawa et al. 2017; Frank 2002; Rempfer et al. 2011). As the dissolved fraction of rivers is defined by a colloidal fraction $(0.20 \mu \mathrm{m}$ or $0.45 \mu \mathrm{m}-1 \mathrm{~nm})$ and a truly dissolved fraction $(<1 \mathrm{~nm})$ (Buffle and Van Leeuwen 1992; Stumm 1993), mineral colloids represent the highest portion of the total $\mathrm{Nd}$ content of natural river waters. The consequence is that $\mathrm{Nd}$ in the marine environment is adsorbed on sub-micro colloids such as Fe-oxyhydroxides or clay minerals or can occur on submicro colloids such as carbonate or rare-earth phosphate minerals.

Direct Nd measurements of Bay of Bengal and Andaman Sea surface seawater suggest a clear link between the riverine input of $\mathrm{Nd}$ associated with discharges and $\varepsilon_{\mathrm{Nd}}$ variations in the northern Indian Ocean (Amakawa and Nozaki 1998; Singh et al. 2012). Using marine sediments of the Bay of Bengal, Burton and Vance (2000), Stoll et al. (2007), Gourlan et al. (2008, 2010), Achyuthan et al. (2014), Braun et al. (2015), Yu et al. (2017), Joussain et al. (2017), and Sebastian et al. (2019) reconstructed past changes in the $\boldsymbol{\varepsilon}_{\mathrm{Nd}}$. Further, Colin et al. (1999), Awasthi et al. (2014), Ali et al. (2015), and Miriyala et al. (2017) reported changes in inputs from the Irrawaddy, Salween, and Sittoung river during the late Pleistocene using Andaman Sea sediments. The authors consistently linked changes in $\boldsymbol{\varepsilon}_{\mathrm{Nd}}$ with the intensity of the
ISM. Cogez et al. (2013) applied two different statistical methods to a global compilation of $\mathrm{Nd}$ isotopes in oceans. The authors showed an important contrast in $\varepsilon_{\mathrm{Nd}}$ between the continental margins and open ocean, and reported that the influence of the margins (where $\mathrm{Nd}$ is injected into the ocean) is important up to a characteristic distance of $3500 \mathrm{~km}$.

\section{Study Objectives}

Using hydrography parameters, Tachikawa et al. (2017) recently established empirical equations predicting the main deepwater $\varepsilon_{\mathrm{Nd}}$ trends and observed that some continental margin basins such as the Bay of Bengal and the Andaman Basin are decoupled from the global trends. The authors argue that the $\varepsilon_{\mathrm{Nd}}$ of seawater and archives are influenced by the local/regional sources and concluded that the detrital influence from the continent is dominant on seawater within $1000 \mathrm{~km}$ of the margins. Additionally, Rempfer et al. (2011) suggested that the boundary exchange between seawater and the continental margins represent the major source ( 90\%) of $\mathrm{Nd}$ and that the $\varepsilon_{\mathrm{Nd}}$ variations resulting in changes in river or dust input are largely constrained to $<1 \mathrm{~km}$ of the water column. In light of the above findings, we hypothesize that changes in the riverine flux into the Bay of Bengal and Andaman Sea related to change in the ISM would be likely reflected by changes in the local/regional seawater $\varepsilon_{\mathrm{Nd}}$. In this study, we present the past $24 \mathrm{ka}$ ISM changes based on $\varepsilon_{\mathrm{Nd}}$ proxy records from the Andaman Sea sediment core RC12-344 (Fig. 1). By extracting the Nd trapped in the carbonate fraction and $\mathrm{Fe}-\mathrm{Mn}$ coatings (interpreted as a paleoseawater signal; Gourlan et al. 2008), we reconstruct changes in the sea-surface conditions.

\section{Potential Sources of $\mathrm{Nd}$ in the Andaman Sea}

The ISS rivers traverse heterogeneous Myanmar bedrock (Fig. 2) resulting in a specific $\varepsilon_{\mathrm{Nd}}$ signature. The Irrawaddy catchment includes Cretaceous to mid-Cretaceous flysch of the western Indo-Burman ranges, Eocene-Miocene, and Quaternary sediments of the Myanmar Central Basin, and the Late Precambrian and Cretaceous-Eocene metamorphic, basic, and ultra-basic rocks of the eastern Himalaya. At present, only two $\varepsilon_{\mathrm{Nd}}$ data $(-10.7$; Colin et al. 1999; -8.3; Allen et al. 2008) are available from the modern river sediments of the Irrawaddy, which were extracted from the silicate fraction. The Salween and eastern Irrawaddy tributaries drain Precambrian, Oligocene-Tertiary sedimentary, and acidic and metamorphic rocks of the eastern Shan Plateau (Socquet and Pubellier 2005). These rivers drain similar catchments 


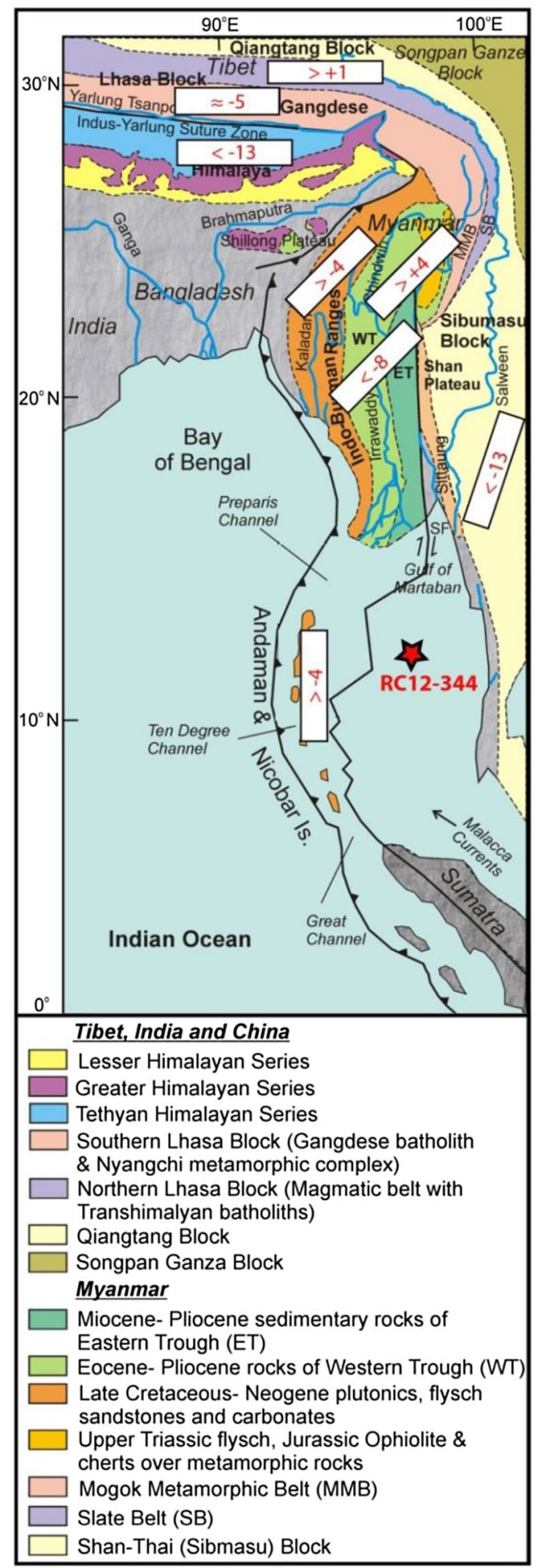

Fig. 2 Source rocks with various $\varepsilon_{\mathrm{Nd}}$ in and around the Andaman Sea and Bay of Bengal (Robinson et al. 2014; Licht et al. 2013; Tripathy et al. 2011; Allen et al. 2008; Chen et al. 2007). Figure has been modified after Robinson et al. (2007) as those of the GBM system. Awasthi et al. (2014) proposed comparable $\varepsilon_{\mathrm{Nd}}$ as the GBM catchment values vary from -18.1 to -13.6 . The Sittoung river drains slates and metamorphic belts like the Salween on the eastern part of the Shan Plateau. Although no $\varepsilon_{\mathrm{Nd}}$ is extant for the Sittoung river, the similarity in the geology to that of the Salween watershed argues in favor of finding comparable $\varepsilon_{\mathrm{Nd}}$ for both the Irrawaddy and Salween rivers.

The Andaman Islands make a minor contribution to the Andaman Sea $\varepsilon_{\mathrm{Nd}}$ budget, because the presence of coral reefs limits sediment discharge (Ray et al. 2011). The modern rivers drain the Paleogene Indo-Burman ranges $\left(\varepsilon_{\mathrm{Nd}} \approx-4\right.$; Allen et al. 2008), and thus the GBM rivers have a smaller impact on the Andaman Sea $\varepsilon_{\mathrm{Nd}}$. The existence of current from the Bay of Bengal to the Andaman Sea (e.g., Ahmad et al. 2005; Awasthi et al. 2014) has been reported. However, the influence of this current is limited due to the bathymetric isolation during the Last Glacial Maximum (LGM). Carbon isotopes in benthic foraminifers suggest an indistinguishable change in water-mass between the Holocene and LGM at site RC12-344 (Naqvi et al. 1994). During the LGM, the sea level dropped by 120-130 m compared to modern sea level, and summer surface circulation was weaker in the Bay of Bengal. If a flow entered the Andaman Sea at that time, it would have been through the Preparis South Channel, which is $\sim 200 \mathrm{~m}$ deep. Any contribution by the surface circulation through this channel into the Andaman Sea is considered negligible due to sea-level lowstand. Therefore, with an annual sediment discharge of $350 \mathrm{MT}$ (Table 1) into the northern Andaman Sea (Ramaswamy et al. 2004), the ISS rivers are the primary contributors to the Andaman Sea $\varepsilon_{\mathrm{Nd}}$ signature.

\section{Materials and Methods}

Core RC12-344 $\left(12.46^{\circ} \mathrm{N}, 96.04^{\circ} \mathrm{E}\right.$; water depth $\left.2.1 \mathrm{~km}\right)$ was retrieved from the Andaman Sea (Fig. 1) during the 1969 $\mathrm{R} / \mathrm{V}$ Robert D. Conrad cruise. For oxygen isotopic $\left(\delta^{18} \mathrm{O}\right)$ measurements, it was subsampled at $2.5-\mathrm{cm}$ intervals for the Holocene and 5-10 cm intervals for the glacial period (Rashid et al. 2007). The $\varepsilon_{\mathrm{Nd}}$ measurement was carried out in coarser resolution than the $\delta^{18} \mathrm{O}$. For $\delta^{18} \mathrm{O}$ and ${ }^{14} \mathrm{C}$-accelerator mass-spectrometer $\left({ }^{14} \mathrm{C}\right.$-AMS $)$ dates, samples were soaked in distilled water overnight and wet-washed using a $63-\mu \mathrm{m}$ sieve.

\subsection{RC12-344 Stratigraphy}

The $\delta^{18} \mathrm{O}$ analysis was carried out on $\sim 4-5$ Globigerinoides ruber (white) from 250 to $355 \mu \mathrm{m}$ size fractions. We used a Thermo Finnigan MAT Delta ${ }^{\text {plus } X L ~ l i g h t ~ s t a b l e ~ i s o t o p e ~}$ ratio mass spectrometer with a Kiel III device. The overall 
analytical reproducibility, as determined from replicate measurements on the carbonate standard NBS-19, is routinely better than $\pm 0.04 \%$ o $( \pm 1 \sigma)$ and $\pm 0.08 \%$ o $( \pm 1 \sigma)$ for $\delta^{13} \mathrm{C}$ and $\delta^{18} \mathrm{O}$ (Rashid et al. 2007), respectively. Nine ${ }^{14} \mathrm{C}$ AMS dates (Table 2) were used to construct the age model, resulting in sedimentation rates of $\sim 19 \mathrm{~cm} / \mathrm{ka}$ and $\sim 10 \mathrm{~cm} /$ ka during the last glacial and Holocene periods (Fig. 3), respectively. The ${ }^{14} \mathrm{C}$-AMS dates were calibrated to calendar years before present (1950) using the CALIB 7.1 and the MARINE13.14C data sets (Stuiver et al. 2019) employing 400 years and $11 \pm 35$ years (Dutta et al. 2001) reservoir and local reservoir $(\Delta \mathrm{R})$ ages, respectively.

\subsection{Analytical Protocol for Seawater Neodymium}

Several methods are currently used to extract seawater $\varepsilon_{\mathrm{Nd}}$ from marine sediments. Sequential acid-reductive leaching (e.g., Bayon et al. 2002; Blaser et al. 2016; Gutjahr et al. 2007; Martin et al. 2010) is a common method. To test the robustness of their new technique, Gourlan et al. (2008, 2010) compared the $\varepsilon_{\mathrm{Nd}}$ obtained by their method, which uses a weak acetic acid $\left(\mathrm{CH}_{3} \mathrm{COOH}\right)$ to extract past seawater signal, and the most common hydroxylamine hydrochloride leaching used to extract the seawater $\varepsilon_{\mathrm{Nd}}$ signal. Gourlan et al. (2010) analyzed 11 marine sediments from different Ocean Drilling Program sites with different ages and $\mathrm{CaCO}_{3}$ concentrations and obtained a good 1:1 correlation, which validates their analytical technique. The results are also in agreement with the study of Martin et al. (2010) showing that acetic leach generally matches with the values obtained by fossil fish teeth and $\mathrm{Fe}-\mathrm{Mn}$ oxides (both considered to preserve a bottom water Nd signature). Moreover, Gourlan et al. (2010) showed that the $\mathrm{Nd}$ (and other rare earth elements, REEs) are mainly associated with the Mn-oxide phase in the sediments and that weak $\mathrm{CH}_{3} \mathrm{COOH}$ used in their method very efficiently dissolves the Mn-oxides. Gourlan et al. (2010) also calculated the Al/Mn and Al/ $\mathrm{Nd}$ of the leachate and bulk sediments and showed that the $\mathrm{CH}_{3} \mathrm{COOH}(1 \mathrm{~N})$ leach preferentially and very efficiently dissolves $\mathrm{Nd}$ and not the silicates. It is important to note that consideration must be given to the possible contamination of the $\varepsilon_{\mathrm{Nd}}$ seawater signal by silicates. Several studies show that archives used to extract seawater composition could suffer from contamination by continental material at varying degrees when samples are deposited proximal to or on the continental margin. For example, Huck et al. (2016) tested the robustness of fossil fish teeth deposited proximal to the continental margin for seawater $\varepsilon_{\mathrm{Nd}}$ reconstructions. The authors analyzed the $\varepsilon_{\mathrm{Nd}}$ composition of cleaned and uncleaned fish teeth from a middle Eocene section deposited proximal to the east Antarctic margin and showed that both methods gave a similar $\varepsilon_{\mathrm{Nd}}$ value, corresponding to mixing between modern seawater and local sediments. Huck et al. (2016) concluded that the fish teeth could be influenced by sedimentary fluxes on shallow marine environments. Moreover, Olivier and Boyet (2006), combining the analyses of REE characteristics and $\varepsilon_{\mathrm{Nd}}$ composition of Jurassic microbialites, show a strong correlation between $\mathrm{Ce} / \mathrm{Ce}^{*}$ and $\varepsilon_{\mathrm{Nd}}$ values. The authors interpreted the $\varepsilon_{\mathrm{Nd}}$ as contamination of relatively pure carbonate (corresponding to seawater signature) by detrital material (named shale signature).

Wilson et al. (2013) also showed that sequential acidreductive leaching might dissolve the detrital material contaminating the leachate and suggested using the method outlined by Gourlan et al. (2008, 2010), who used acetic acid $\left(\mathrm{CH}_{3} \mathrm{COOH}\right)$ leaching on non-decarbonated sediments for extracting an authigenic $\varepsilon_{\mathrm{Nd}}$ signal.

In this study, we used a simple and quick protocol described by Gourlan et al. $(2008,2010)$ to measure seawater $\varepsilon_{\mathrm{Nd}}$, which consists of treatment of $300-400 \mathrm{mg}$ of

Table $2{ }^{14} \mathrm{C}$-AMS dates of the Andaman Sea sediment core RC12-344

\begin{tabular}{llllrrr}
\hline & Lab ID & Depth $(\mathrm{cm})$ & Species & ${ }^{14}$ C-AMS dates & \multicolumn{2}{c}{$\begin{array}{l}\text { Calibrated age (years } \\
\text { BP; } 1 \sigma)^{\mathrm{a}}\end{array}$} \\
\hline 1 & UCIAMS17383 & $10-11$ & Mixed planktonic & $2005 \pm 50$ & $1479-1640$ & Rashid et al. (2007) \\
2 & UCIAMS35383 & $28-29$ & Mixed planktonic & $2895 \pm 25$ & $2611-2728$ & Rashid et al. (2007) \\
3 & UCIAMS16832 & $58-60$ & Mixed planktonic & $6695 \pm 20$ & $7168-7252$ & Rashid et al. (2007) \\
4 & UCIAMS16833 & $135-137$ & Mixed planktonic & $9575 \pm 20$ & $10,372-10,507$ & Rashid et al. (2007) \\
5 & UCIAMS17384 & $175-176$ & Mixed planktonic & $11,050 \pm 25$ & $12,545-12,631$ & Rashid et al. (2007) \\
7 & UCIAMS16836 & $234-235$ & Mixed planktonic & $13,250 \pm 30$ & $15,189-15,372$ & Rashid et al. (2007) \\
9 & UCIAMS16837 & $275-277$ & Mixed planktonic & $14,890 \pm 30$ & $17,537-17,726$ & Rashid et al. (2007) \\
10 & UCIAMS35384 & $335-337$ & Mixed planktonic & $16,750 \pm 40$ & $19,600-19,811$ & Rashid et al. (2007) \\
11 & UCIAMS35385 & $415-417$ & Mixed planktonic & $18,960 \pm 60$ & $22,353-22,488$ & Rashid et al. (2007) \\
\hline
\end{tabular}

${ }^{a}$ All ${ }^{14} \mathrm{C}$-accelerator mass-spectrometer $\left({ }^{14} \mathrm{C}\right.$-AMS $)$ dates were determined on the mixed planktonic foraminifers. The ${ }^{14} \mathrm{C}$-AMS dates were obtained at the Keck Carbon Cycle laboratory of the University of California, Irvine. ${ }^{14} \mathrm{C}$-AMS dates were converted to calendar years before present (1950) using the calibration program (CALIB 7.1) of Stuiver et al. (2019) utilizing the MARINE13.14C dataset. We employed a local reservoir $(\Delta R)$ correction of $11 \pm 35$ years following Dutta et al. (2001) 
Fig. 3 a Downcore planktonic Globigerinoides ruber (white) $\delta^{18} \mathrm{O}$, estimate of the Irrawaddy and Salween river contributions to seawater $\varepsilon_{\mathrm{Nd}}$ budget and seawater $\varepsilon_{\mathrm{Nd}}$ (and maximum error bars) from Andaman Sea core RC12-344; b sedimentation rates $(\mathrm{cm} / \mathrm{ka})$ derived by extrapolating ${ }^{14} \mathrm{C}$-AMS dates (Table 2), which are calibrated to calendar years using the CALIB program employing 400 years and $11 \pm 35$ years reservoir and local reservoir $(\Delta R)$ ages, respectively, are plotted. Note that the vertical discontinuous lines in (a) guide the abrupt climate transitions. Seawater $\varepsilon_{\mathrm{Nd}}$ data are given in Table S1

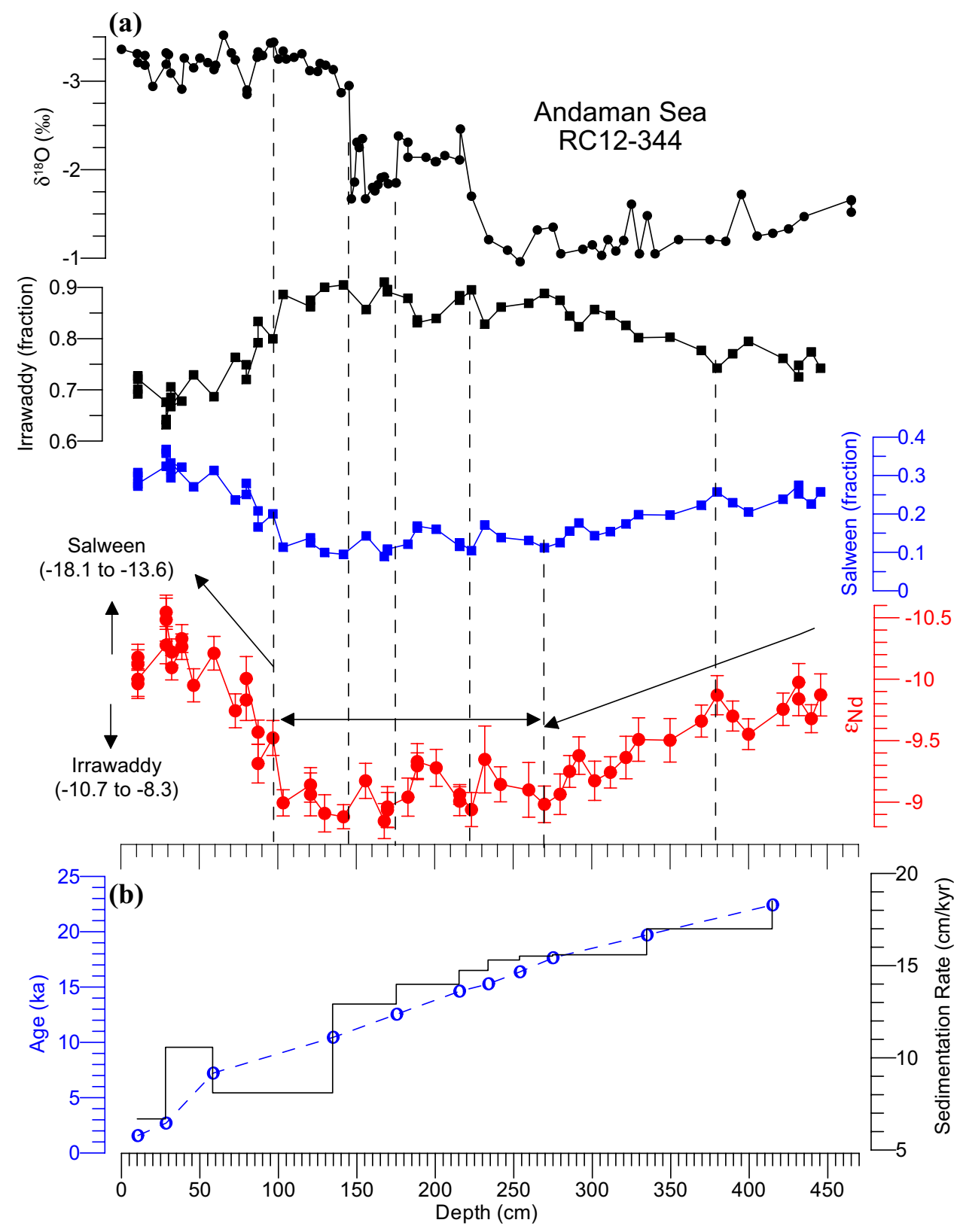

pulverized sediments by $\mathrm{CH}_{3} \mathrm{COOH}(1 \mathrm{~N})$ in excess. This leaching allows total dissolution of the carbonate fraction and most of the Mn-oxides around microfossils in which the seawater $\varepsilon_{\mathrm{Nd}}$ is trapped (Gourlan et al. 2008). The supernatant fluid, carrying the seawater signal, was collected and evaporated. Nd was separated from the leachate in two steps. The REEs were separated on a Bio-Rad column (AG 50W$\mathrm{X} 8$ cationic resin). The $\mathrm{Nd}$ was then isolated from the other REEs on an REE-specific resin (Eichrom ${ }^{\circledR}$ Ln-Spec) using $0.180 \mathrm{M} \mathrm{HCl}$ acid. The $\varepsilon_{\mathrm{Nd}}$ were measured on a Nu Plasma MC-ICP-MS in the ENS-Lyon laboratory and corrected for mass fractionation to ${ }^{146} \mathrm{Nd} /{ }^{144} \mathrm{Nd}=0.7219$. The Rennes $\mathrm{Nd}$ standard was run regularly and provided a ${ }^{143} \mathrm{Nd} /{ }^{144} \mathrm{Nd}$ of $0.511964 \pm 0.000019$ ( $2 \sigma$ standard deviation, $n=34)$.
A bracketing method was applied to correct $\varepsilon_{\mathrm{Nd}}$ for bias using the Rennes Nd standard value (Chauvel and BlichertToft 2001). Total procedural blank was below $80 \mathrm{pg}$ of $\mathrm{Nd}$ $(n=5)$. The $\varepsilon_{\mathrm{Nd}}$ data are given in the supporting information (Table S1).

\section{Results}

To avoid repetition, the G. ruber $\delta^{18} \mathrm{O}$ were not detailed here, as most of these data were described in Rashid et al. (2007). However, briefly, $\delta^{18} \mathrm{O}$ range from -1.5 to $-1.7 \%$ o between 465 and $223 \mathrm{~cm}$ (Fig. 3). A transition from high to low $\delta^{18} \mathrm{O}$ is found between 230 and $220 \mathrm{~cm}$. In comparison to the 
interval between 465 and $223 \mathrm{~cm}$, low $\delta^{18} \mathrm{O}$ are observed between 216 and $175 \mathrm{~cm}$. The interval between 175 and $156 \mathrm{~cm}$ shows $\delta^{18} \mathrm{O}$ that are relatively low compared to the interval between 465 and $223 \mathrm{~cm}$ but higher than those of the $\delta^{18} \mathrm{O}$ between 220 and $175 \mathrm{~cm}$. The interval between 145 and $0 \mathrm{~cm}$ shows an average of $-3.2 \%$, with no major fluctuations.

In contrast to the $\delta^{18} \mathrm{O}$, seawater $\varepsilon_{\mathrm{Nd}}$ data show an interesting structure (Fig. 3). The $\varepsilon_{\mathrm{Nd}}$ data can be partitioned into four trends: (1) a gradual change from less $(\sim-10)$ to more ( -9) radiogenic between 445.5 and $269.5 \mathrm{~cm},(2)$ a stable interval from 269.5 to $96.5 \mathrm{~cm}$ in which $\varepsilon_{\mathrm{Nd}}$ are relatively stable with occasional minor fluctuation, (3) a gradual change from -9.5 to -9.7 between 96.5 and $72.5 \mathrm{~cm}$, and (4) a stable value of $\sim-10.2$ between 72.5 and $10.5 \mathrm{~cm}$ (Fig. 3).

\section{Discussion}

\subsection{The Andaman Sea LGM and Deglacial Climate}

To place our Andaman Sea $\varepsilon_{\mathrm{Nd}}$ data into broader Indo-Asian monsoon context, we plotted the available high-resolution terrestrial ISM proxy records in Fig. 4. A few available $\varepsilon_{\mathrm{Nd}}$
Fig. 4 A few selected IndoAsian monsoon paleo-proxy records are plotted according to their independent age models. a $G$. ruber $\delta^{18} \mathrm{O}$ and $\mathbf{b}$ seawater $\varepsilon_{\mathrm{Nd}}$ (red circles, this study) from the Andaman Sea core RC12344 and $\varepsilon_{\mathrm{Nd}}$ (black circles) from the western Andaman Sea core SC-03-2008 (Achyuthan et al. 2014); and c central Andaman Sea core SK234-60 (Awasthi et al. 2014) $\varepsilon_{\mathrm{Nd}}$ record; d $\delta$ D-alkanes of northern Bay of Bengal core SO188-342KL (Contreras-Rosales et al. 2014); speleothems $\delta^{18} \mathrm{O}$ of (e) Oman (red) (Shakun et al. 2007) and Yemen (blue) (Fleitmann et al. 2007) of western Arabian Sea; speleothems $\delta^{18} \mathrm{O}$ of (f) Timta (blue) (Sinha et al. 2005) and Mawmluh (black; Berkelhammer et al. 2012; and green; Dutt et al. 2015) and $\delta^{18} \mathrm{O}$ of gastropod aragonite (red) of paleolake Kotla-Dahar from India (Dixit et al. 2014); $\mathbf{g}$ Dongge/Hulu speleothems $\delta^{18} \mathrm{O}$ (Dykoski et al. 2005; Wang et al. 2001); and h solar insolation (August) at $20^{\circ} \mathrm{N}$ latitude (Laskar et al. 2004). Downward arrows are the ${ }^{14} \mathrm{C}$-AMS dates used to construct the age model of RC12-344. EH and $L H$ Early and Late Holocene, $Y D$ Younger Dryas, $B / A$ B $ø$ lling-Allerød, LGM Last Glacial Maximum

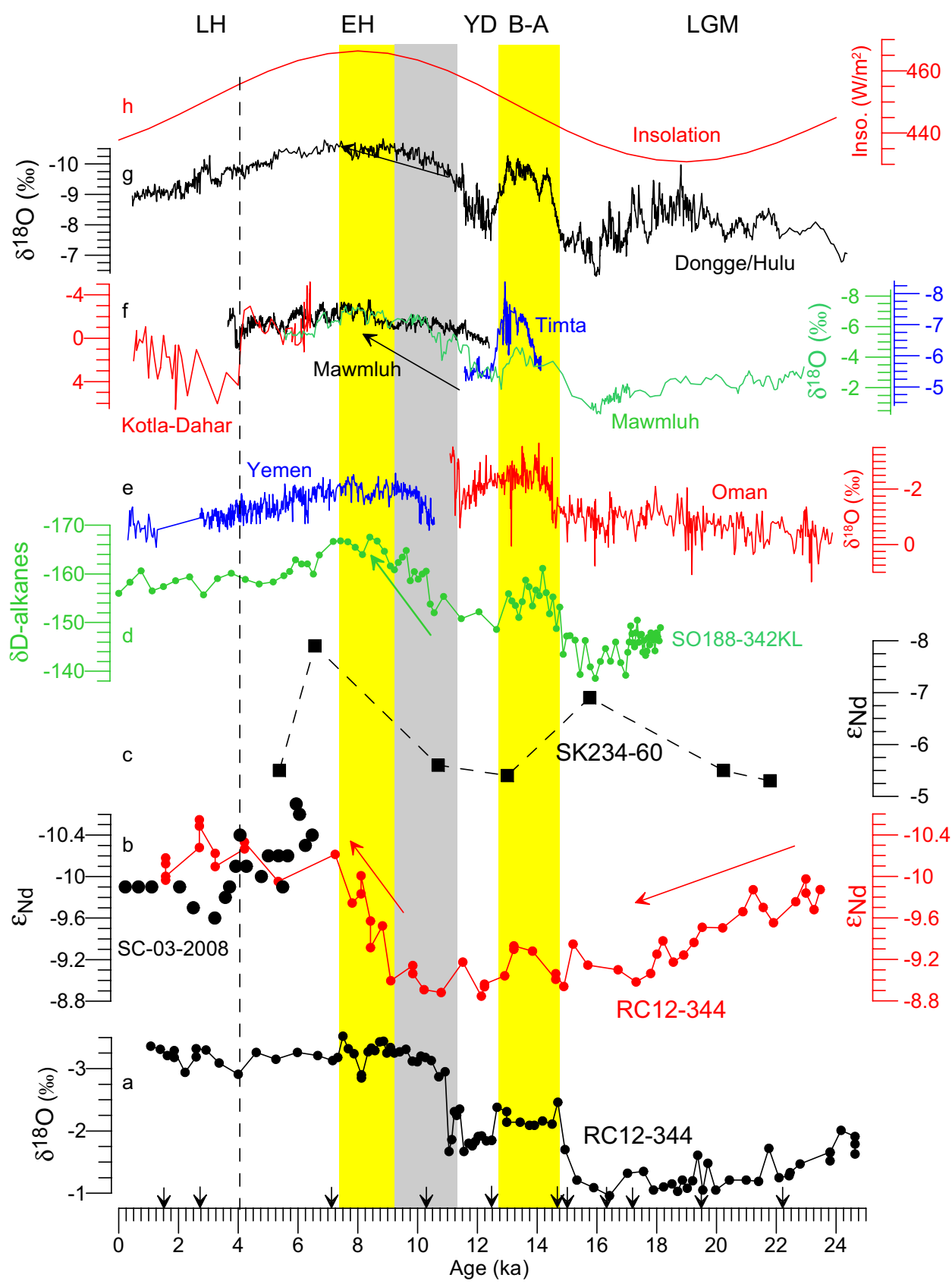


data from the Andaman Sea and Bay of Bengal are also plotted (Achyuthan et al. 2014; Awasthi et al. 2014). Over a general increasing $\varepsilon_{\mathrm{Nd}}$ trend from -10.1 to -9 , a few millennial- to centennial-scale less radiogenic $\varepsilon_{\mathrm{Nd}}$ events between 22.2 and $16.2 \mathrm{ka}$ in the RC12-344 have equivalent low $\delta^{18} \mathrm{O}$ events in the Dongge and Mawmluh speleothems (Fig. 4f, g). These synchronous events reflect changes in the intensity of the ISM. Further, the $\delta \mathrm{D}$-alkanes between 18.2 and $17 \mathrm{ka}$ (Fig. 4d) are also low, consistent with the low $\delta^{18} \mathrm{O}$ of Dongge and Mawmluh and an equivalent $\varepsilon_{\mathrm{Nd}}$ event of a slight increase at RC12-344, also suggesting a reduced ISS outflow. Between 17.2 and $8.8 \mathrm{ka}$, the seawater $\varepsilon_{\mathrm{Nd}}$ are relatively stable (Fig. 4b), with a minor rise in less radiogenic values in the warm $\mathrm{B} \varnothing$ lling-Allerød period.

The warm B/A and cold YD periods are clearly identified in the RC12-344 $\delta^{18} \mathrm{O}$ (Fig. 4a), consistent with the Indian and Chinese speleothems $\delta^{18} \mathrm{O}$ (Fig. $4 \mathrm{e}-\mathrm{g}$ ) and $\delta \mathrm{D}$-alkanes of Bay of Bengal core SO188-342KL (Fig. 4d). In contrast to the speleothems $\delta^{18} \mathrm{O}$, the Andaman Sea $\varepsilon_{\mathrm{Nd}}$ are less radiogenic during the $\mathrm{B} / \mathrm{A}$, indicating increased discharge from the ISS rivers. Such fluctuation in $\varepsilon_{\mathrm{Nd}}$ is insignificant given that the other ISM paleo-proxy records (Fig. 4) show dramatic changes. For example, the foraminifera and speleothems $\delta^{18} \mathrm{O}$ and $\delta \mathrm{D}$-alkanes show clear and sharp changes in $\mathrm{B} / \mathrm{A}$ and $\mathrm{YD}$ suggesting strong/wet and weak/dry Indo-Asian monsoons (Rashid et al. 2011; Dutt et al. 2015), respectively.

\subsection{Andaman Sea Holocene Climate}

\subsubsection{Early to Mid-Holocene}

Between 9.1 and $7.2 \mathrm{ka}$, a rapid change from more to less radiogenic $\varepsilon_{\mathrm{Nd}}$ is identified. This transition during the early Holocene is in sharp contrast to the abrupt change in which the transition from high to low $\delta^{18} \mathrm{O}$ in foraminifera occurred at $11 \mathrm{ka}$ (Fig. 4a). It may suggest a lag between the terrestrial erosion and $\varepsilon_{\mathrm{Nd}}$ signature at RC12-344. Further, the regional changes of the ISM recorded in the $\delta \mathrm{D}$-alkanes, Mawmluh $\delta^{18} \mathrm{O}$, and seawater $\varepsilon_{\mathrm{Nd}}$ show heterogeneous strength of the ISM. The rapid transition from high to low $\delta$ D-alkanes occurred between 10.9 and $9.2 \mathrm{ka}$ (Fig. 4d), representing changes from less to more rainfall, and hence a weak and dry to strong and wet ISM (Contreras-Rosales et al. 2014). The lowest $\delta \mathrm{D}$-alkanes were found between 9.2 and $7.2 \mathrm{ka}$, suggesting the highest runoff associated with the strongest and wettest ISM. This is also in agreement with the work by Joussain et al. (2017) on sediments from the active channellevel systems of the northern Bengal fan, which suggest that this period corresponds to the maximum ISM rainfall, with an increase in detrital material. The Mawmluh $\delta^{18} \mathrm{O}$ show two-step ISM intensification: (1) between 11.2 and $9.2 \mathrm{ka}$, $\delta^{18} \mathrm{O}$ ranging from -6.1 to $-5.8 \%$, which suggests a gradual intensification from weak and dry to strong and wet ISM; and (2) the lowest $\delta^{18} \mathrm{O}$ between 9.2 and $7.3 \mathrm{ka}$, indicating the strongest and wettest ISM (Berkelhammer et al. 2012). In summary, the Andaman Sea $\varepsilon_{\mathrm{Nd}}$ trend during the early Holocene is not a stand-alone feature of the ISM, but confirms a similar regional trend found in the highly resolved Mawmluh $\delta^{18} \mathrm{O}$ of NE India and the $\delta \mathrm{D}$-alkanes from the Bay of Bengal.

\subsubsection{Mid- to Late Holocene}

An interpolated age of $1.5 \mathrm{ka}$ corresponds to $\varepsilon_{\mathrm{Nd}}$ of -10.1 at $10.5 \mathrm{~cm}$ sub-bottom depth of RC12-344, which is closer to the modern Andaman Sea seawater $\varepsilon_{\mathrm{Nd}}$ at PA-S10 (Amakawa et al. 2000). No major fluctuation in $\varepsilon_{\mathrm{Nd}}$ is observed between 7.2 and $1.5 \mathrm{ka}$ (Fig. 4b). However, higherresolution $\varepsilon_{\mathrm{Nd}}$ data for the past $6.5 \mathrm{ka}$ (Fig. 4b) show fluctuations on the western Andaman Sea (Achyuthan et al. 2014). The variations observed in $\varepsilon_{\mathrm{Nd}}$ were explained by the mixing between (1) a less radiogenic end-member corresponding to greater input of solutes from the Indian subcontinent, and hence higher rainfall, and (2) a more radiogenic endmember which corresponds to lower rainfall on the continent and greater input of solute from the island-arc rocks in the western Andaman Islands. In comparison to the $\varepsilon_{\mathrm{Nd}}$ of Achyuthan et al. (2014), the paleolake Kotla Dahar gastropod aragonite (Fig. 4f) shows a change from low to high $\delta^{18} \mathrm{O}$ (Dixit et al. 2014). These progressively higher $\delta^{18} \mathrm{O}$ were explained by less rainfall and hence a weaker ISM, consistent with the earlier findings (Rashid et al. 2011; Clift et al. 2012) and recent studies in the Bengal fan (Joussain et al. 2017; Hein et al. 2017). The $\varepsilon_{\mathrm{Nd}}$ range from -9.6 to -10.7 at SC-03-2008 cannot be compared to the RC12-344 $\varepsilon_{\mathrm{Nd}}$ due to the coarse resolution for the past $6.5 \mathrm{ka}$. Further, the site SC-03-2008 is located close to the Andaman Islands, which may have received sediments of andesitic and dacitic volcanic rocks from northern Andaman and Landfall Islands. Those igneous rocks have more radiogenic $\varepsilon_{\mathrm{Nd}}$ than those of the ISS catchments (Ray et al. 2011).

\subsection{New Andaman Sea Record and Regional Monsoonal Climate}

Potential sources (Table 1) for the Andaman Sea $\varepsilon_{\mathrm{Nd}}$ are briefly outlined above. Divergent $\varepsilon_{\mathrm{Nd}}$ enters into the Andaman Sea at different points due to the diversity of basement rocks (Robinson et al. 2014) as well as changes in relative proportions through time. Moreover, the average $\varepsilon_{\mathrm{Nd}}$ of the Indian Ocean seawater is $-8 \pm 2.5$ (Piepgras et al. 1979; Singh et al. 2012; Cogez et al. 2013), which is the result of mixing by (1) Atlantic waters inputs $(-9.2 \pm 1.5$; Jeandel 1993), (2) Indonesian throughflow ( $-4 \pm 1$; Amakawa et al. 2000), and (3) Himalayan river discharge ( $-14 \pm 3$; Goldstein and Jacobsen 1987; Yu et al. 2017). The contribution 
from the northern Indian Ocean water masses to the Andaman Sea is negligible (Amakawa et al. 2000; Singh et al. 2012). The strong heterogeneities in $\varepsilon_{\mathrm{Nd}}$ (close to the continental margins; Rempfer et al. 2012) are observed locally due to the short residence time of $\mathrm{Nd}$ compared to the mixing time of oceans (Frank 2002). Therefore, we propose that any change in the $\varepsilon_{\mathrm{Nd}}$ at RC12-344 lies mostly within the variable contributions by the ISS rivers, with a minor contribution from the northern Indian Ocean water masses (Amakawa et al. 2000; Singh et al. 2012). Further, we hypothesize that the fluctuations in $\varepsilon_{\mathrm{Nd}}$ are linked to a reduction or an increase in the discharge as a function of dilution. In this reasoning, the contribution of the ISS rivers increases or decreases synchronously with the discharge derived by strengthening or weakening of the ISM. In other words, discharge from every river increases or decreases in equal proportion, without recognizing the heterogeneity of the ISS catchments and their proportional contribution to the Andaman Sea $\varepsilon_{\mathrm{Nd}}$.

A binary mixing model between the Irrawaddy (more radiogenic end-member) and the Salween (less radiogenic end-member) rivers supports the other possibility. In this understanding, different rivers contribute in different proportions. We consider that the Sittoung River has a very limited impact on the ISS systems because of its low discharge and the "distance limit principle" in which only the local input controls the $\varepsilon_{\mathrm{Nd}}$ (Cogez et al. 2013). In such a scenario, a binary mixing equation can be written as follows:

$\varepsilon_{\mathrm{Nd}}^{\mathrm{AS}}=\varepsilon_{\mathrm{Nd}}^{\mathrm{IR}} \alpha+\varepsilon_{\mathrm{Nd}}^{\mathrm{SR}}(1-\alpha)$,

where AS is the Andaman Sea core RC12-344 $\varepsilon_{\mathrm{Nd}}$, IR is the Irrawaddy river, $\mathrm{SR}$ is the Salween river, and $\alpha$ is the mass fraction (unknown) from the Irrawaddy freshwater $\mathrm{Nd}$, equal to the mass of $\mathrm{Nd}$ dissolved fraction coming from the Irrawaddy river, on the total mass of $\mathrm{Nd}$ in the water at RC12-344.

Modern river water $\varepsilon_{\mathrm{Nd}}$ of the Irrawaddy and Salween is not well constrained; moreover, only the modern sediments of these rivers were analyzed. Nevertheless, Goldstein and Jacobsen (1987) showed that the dissolved $\mathrm{Nd}$ and detrital $\mathrm{Nd}$ in GB rivers are isotopically identical within $\pm 0.5 \varepsilon_{\mathrm{Nd}}$. Therefore, in most cases, the $\varepsilon_{\mathrm{Nd}}$ of the suspended load is a good approximation of $\varepsilon_{\mathrm{Nd}}$ of river waters. This agrees with the work of Singh et al. (2012) and is consistent with the findings of Chapman et al. (2015), in which the authors analyzed major elements and $\mathrm{Sr}$ isotopes of the Irrawaddy and Salween rivers. The authors demonstrated that water chemistry reflects the bedrock geology of both rivers. Taking into account these findings, our $\varepsilon_{\mathrm{Nd}}$ data and the range of $\varepsilon_{\mathrm{Nd}}^{\mathrm{IR}}$ and $\varepsilon_{\mathrm{Nd}}^{\mathrm{SR}}$ values (Fig. 3), the $\varepsilon_{\mathrm{Nd}} \varepsilon_{\mathrm{Nd}}^{\mathrm{IR}}=-8.3$ and $\varepsilon_{\mathrm{Nd}}^{\mathrm{SR}}=-14.4$ can reasonably be used for our model (Gourlan et al. 2010). Consequently, we estimated the contribution of both endmembers to the Andaman Sea for the changes in $\varepsilon_{\mathrm{Nd}}$ in four steps: (1) during the gradual change from less to more radiogenic $\varepsilon_{\mathrm{Nd}}$ between 24.6 and $17.2 \mathrm{ka}$, the contribution from the Irrawaddy river increased from $\approx 73 \%$ to $89 \%$ and the contribution from the Salween river decreased from $\approx 27 \%$ to $11 \%$; (2) the contributions from both the Irrawaddy and Salween rivers remained stable (87-13\% each) through the relatively stable interval between 17.2 and $8.8 \mathrm{ka}$; (3) the contribution from the Irrawaddy and Salween rivers decreased and increased, respectively, in the period between 8.8 and $6 \mathrm{ka}$. This proportional contribution between two rivers potentially allowed a gradual change from more to less radiogenic $\varepsilon_{\mathrm{Nd}}$ that eventually stabilized to -10.2 ; and finally, (4) the contribution from the Irrawaddy and Salween rivers accounted for $68 \%$ and $32 \%$, respectively, for the late Holocene.

There are several uncertainties in estimating $\alpha$ due to the wide range in the $\varepsilon_{\mathrm{Nd}}$ end-members of both rivers. Consequently, we estimated the error range of the mixing ratio and calculated average values for both contributions for the past $24 \mathrm{ka}$. It is important to emphasize that due to a minimal value of -8.9 obtained for the RC12-344 sediments, the Irrawaddy river $\varepsilon_{\mathrm{Nd}}$ must be close to the value proposed by Allen et al. (2008). So, taking into account the higher and lower isotopic values of the Irrawaddy river, we estimated (1) an increase in the contribution by the Irrawaddy from $\approx 76 \pm 7 \%$ to $90 \pm 7 \%$ and a decrease from $\approx 24 \pm 7 \%$ to $10 \pm 3 \%$ by the Salween before $17.2 \mathrm{ka}$; (2) then contributions remained $\approx 89 \pm 2 \%$ for the Irrawaddy and $12 \pm 4 \%$ for the Salween during the stable interval between 17.2 and $8.8 \mathrm{ka}$; (3) the estimation remained the same from 8.8 to $6 \mathrm{ka}$; and (4) the Irrawaddy and Salween river contributions were estimated to be $\approx 72 \pm 8 \%$ and $28 \pm 8 \%$, respectively, for the recent period. In any event, the Irrawaddy river plays a major role in this binary mixing model.

Moreover, the parameter considered to change the $\varepsilon_{\mathrm{Nd}}$ at site $\mathrm{RC12-344}$ is the variation in the mass of freshwater coming from each end-member. Obviously, the Nd concentrations of each river have an impact on the $\varepsilon_{\mathrm{Nd}}$. Nevertheless, it is extremely difficult (to date impossible) to reconstruct the past Nd concentrations. Gaillardet and Dupré (2014) analyzed and compiled trace elemental abundances in the dissolved load of many rivers worldwide and showed spatial variability between 2 and $500 \mathrm{ng} / \mathrm{L}$ in $\mathrm{Nd}$ dissolved concentrations in rivers. In general, the dissolved Nd concentration in Himalayan rivers is estimated using tributaries collected in a unique period, such as for $\mathrm{G}-\mathrm{B}$ dissolved $\mathrm{Nd}$ input into the Bay of Bengal, where the Yamuna river collected in the Southwest monsoon (SWM) period is used as representative of the whole Ganges river (Yu et al. 2017). The only available value from the Indus river is $0.003 \mathrm{ng} / \mathrm{L}$ (Gaillardet and Dupré 2014). Chapman et al. (2015) recently published data for the Irrawaddy and Salween rivers. Unfortunately, no Nd data were obtained; only major elements 
and $\mathrm{Sr}$ isotopic ratios were determined. To summarize, the concentrations of the REEs of the Himalayan rivers are not well documented. The main reason is their low abundance, which implies that a change in the concentrations will have a negligible impact on the mixing model. For these reasons, we favor the mixing model involving constant concentrations for each river through time.

There is evidence to support our new $\varepsilon_{\mathrm{Nd}}$ estimate. For example, our findings are in agreement with those of Awasthi et al. (2014), in which a three-component mixing model was proposed. In that model, contributions of the Irrawaddy, Salween-Sittoung and Ganga-Brahmaputra (SS-GB), and Indo-Burman-Arakan and Andaman Islands are quantified for the late Holocene. Further, Awasthi et al. (2014) proposed a ternary mixing grid by plotting $\varepsilon_{\mathrm{Nd}}$ versus ${ }^{87} \mathrm{Sr} /{ }^{86} \mathrm{Sr}$ to delineate the contributions of the Indo-Burman-Arakan-Andaman, Irrawaddy, and SS-GB rivers at SK234-60 (Fig. 1). The more radiogenic $\varepsilon_{\mathrm{Nd}}$ at site SK23460 are most likely derived from the igneous and volcanic rocks of the Andaman Islands, which are plentiful on the western Andaman Sea. It should be noted that the $\varepsilon_{\mathrm{Nd}}$ and ${ }^{87} \mathrm{Sr} /{ }^{86} \mathrm{Sr}$ data used in the plot were determined in the silicate fraction. In any event, our mixing model, and following Awasthi et al. (2014), suggests that the first two sources were the main detrital sediment suppliers at RC12-344, with a contribution of $80-50 \%$ for Irrawaddy, and the SS-GB accounting for $20-35 \%$. Colin et al. (1999) obtained two $\varepsilon_{\mathrm{Nd}}$ data (i.e., $2 \mathrm{ka} ;-11.3$ and $\left.19.2 \mathrm{ka} ;-11.5\right)$ from core RC12-344 in the silicate fraction. Those $\varepsilon_{\mathrm{Nd}}$ diverge from our RC12-344 $\varepsilon_{\mathrm{Nd}}$ data by more than one epsilon unit, which is expected given that the extraction of $\varepsilon_{\mathrm{Nd}}$ was carried out in two different phases. In fact, a possible offset between the Nd particulate (detrital material) and the $\mathrm{Nd}$ dissolved (seawater) fractions was observed and explained in several studies (e.g., Goldstein and Jacobsen 1987; Rousseau et al. 2015; Jeandel and Oelkers 2015).

It is well known that the detrital fraction enables identification of the sources, while the dissolved fraction reflects the intensity of continental weathering, sources, and changes in paleocirculation (Frank 2002). Consequently, it is expected that the detrital and dissolved fractions can have different $\mathrm{Nd}$ isotopic values. Moreover, several studies reported $\varepsilon_{\mathrm{Nd}}$ differences between the two fractions. For example, Goldstein and Jacobson (1987) suggested a difference of some $\varepsilon_{\mathrm{Nd}}$ units between the $\varepsilon_{\mathrm{Nd}}$ suspended and dissolved river loads. Jeandel and Oelkers (2015) recently demonstrated that an important dissolution of the particulate fraction occurs in seawater after its arrival in the ocean (desorption and exchange processes also occurred). Rousseau et al. (2015) analyzed the dissolved, particulate, and colloidal $\varepsilon_{\mathrm{Nd}}$ values of the Amazon estuary and showed an offset between particulate and dissolved $\varepsilon_{\mathrm{Nd}}$ values. These authors also suggested that the dissolved $\mathrm{Nd}$ is a mixture of the dissolved
$\mathrm{Nd}$ from the suspended particulate matter, the remaining river fraction, and the ocean seawater end-member. This showed that the dissolved Nd fractions could be modified by the release of $\mathrm{Nd}$ from the suspended particulate matter (a process which increases with the salinity) and its removal by colloid coagulation. These processes are controlled by several parameters, including the mineralogy of suspended particulate matter, $\mathrm{pH}$, and dissolved organic carbon, and could modify the $\varepsilon_{\mathrm{Nd}}$ values of the dissolved fraction and also explain in part $\varepsilon_{\mathrm{Nd}}$ differences observed between the detrital and dissolved fractions in marine sediments. Finally, smaller quantities of particulates are transported far from their sources into the oceans (Milliman and Farnsworth 2011). This transport over long distances may also affect the detrital $\varepsilon_{\mathrm{Nd}}$ values and emphasize the offset between detrital and dissolved $\varepsilon_{\mathrm{Nd}}$ values.

Our findings are consistent with the theory proposed by Colin et al. (1999) that the Irrawaddy river was the main contributor of detrital sediment to the northeastern Andaman Sea. It is possible that variations in $\varepsilon_{\mathrm{Nd}}$ might be due to internal changes in the end-member composition, which cannot be ruled out entirely. However, it would be surprising that internal change would occur without having any driver, i.e., changes in the intensity of terrestrial erosion. More erosion will not necessarily add more Nd. Nevertheless, the fluctuations in contributions by the ISS rivers correlate well with the other ISM paleo-proxy records. Therefore, we favor the proposal that the Irrawaddy river remained the main contributor of seawater $\varepsilon_{\mathrm{Nd}}$ for the past $24 \mathrm{ka}$ and the $\varepsilon_{\mathrm{Nd}}$ signature of Andaman Sea results from a mixture of $\mathrm{Nd}$ derived from the ISS rivers.

The latest (Dutt et al. 2015) and earlier (Berkelhammer et al. 2012) Mawmluh caves $\delta^{18} \mathrm{O}$ data in conjunction with the Timta (Sinha et al. 2005), Dandak and Gupteswar (Yadava and Ramesh 2005), and Baratang (Laskar et al. 2013) caves $\delta^{18} \mathrm{O}$ records provide the past $36 \mathrm{ka}$ ISM records for the first time from the Indian subcontinent. The glacial ISM records (Fig. 4a) tightly correlate with those of the Chinese speleothems and Greenland ice cores, which is explained by the ITCZ and sea-ice coupling in the north Atlantic (Battisti et al. 2014). However, this coupling between the polar climate and Indo-Asian monsoon breaks down for the Holocene as the Tibetan Plateau ice-cores (Rashid et al. 2011, 2013) as well as the data presented here. The Holocene records from Oman (Fleitmann et al. 2003) and Yemen (Shakun et al. 2007) show some degree of similarity with the Mawmluh speleothems (Berkelhammer et al. 2012). The major transition from the deglacial to $\mathrm{B} / \mathrm{A}$ at $14.6 \mathrm{ka}$ in Yemeni speleothems is abrupt but the transition from the $\mathrm{B} / \mathrm{A}$ to $\mathrm{YD}$ is gradual, not the abrupt change observed in the new Mawmluh cave and other paleoproxy records (Fig. 4). However, the new Andaman Sea $\varepsilon_{\mathrm{Nd}}$ and Mawmluh $\delta^{18} \mathrm{O}$ show a strong correlation that suggests 
similar changes recorded in both proxies. The discrepancies between the Arabian Sea/Chinese speleothems and Indian subcontinent paleo-monsoon proxies may be due to the location of the records, in that the former records are located on the fringe of the ISM, whereas the latter records are located directly in the monsoon domain (Berkelhammer et al. 2012). Therefore, the Arabian Sea/Chinese paleo-monsoon proxies lacked the ISM sensitivity of northeastern India, especially for the Holocene. Taken together with the Mawmluh cave $\delta^{18} \mathrm{O}$ and our new $\varepsilon_{\mathrm{Nd}}$ data, this suggests a consistent variability in the ISM strength for the past $24 \mathrm{ka}$.

\section{Summary and Conclusions}

Seawater $\varepsilon_{\mathrm{Nd}}$ for the past $24 \mathrm{ka}$ were determined from the Andaman Sea sediment core RC12-344. The new $\varepsilon_{\mathrm{Nd}}$ data were used as a proxy to assess the strength of the past ISM and discharge by the Irrawaddy-Salween and Sittoung rivers. The Andaman Sea $\varepsilon_{\mathrm{Nd}}$ trend agrees with the other pastISM proxy records, namely speleothems, and marine and lake sediments, and suggests coherent changes in peninsular India. New data show four trends: (1) a gradual change from less to more radiogenic $\varepsilon_{\mathrm{Nd}}$ between 24 and $17.2 \mathrm{ka}$, (2) a stable interval from 17.2 to $8.8 \mathrm{ka}$ in which the $\varepsilon_{\mathrm{Nd}}$ is relatively stable with occasional minor fluctuations, (3) a gradual change from more to less radiogenic $\varepsilon_{\mathrm{Nd}}$ between 9 and $7 \mathrm{ka}$, and (4) a stable, less radiogenic $\varepsilon_{\mathrm{Nd}}$ since $7 \mathrm{ka}$. As the river discharge is closely linked to the ISM, we propose a binary mixing model involving the Irrawaddy and Salween-Sittoung outflow to determine the evolution of the Andaman Sea seawater $\varepsilon_{\mathrm{Nd}}$. We hypothesize that the Irrawaddy river remained the main contributor of seawater $\varepsilon_{\mathrm{Nd}}$ for the past $24 \mathrm{ka}$. However, our hypothesis can be further tested by acquiring additional background geochemical data for Myanmar rivers.

Acknowledgements HR wishes to acknowledge support from the Research and Development Corporation (RDC) of the province of Newfoundland and Labrador and the Atlantic Canada Opportunities Agency (ACOA). M.-J. Zhu, J.-L. Xing, M. Vermooten, and M.-Q. Dong are thanked for their help in processing sediment samples. The Lamont-Doherty Earth Observatory of Columbia University, Palisades, NY is acknowledged for providing samples for the study. This study also benefited from financial support from Joseph Fourier University and the INSU program "SYSTER". Julian Dust and other anonymous reviewers are thanked for their constructive and useful comments to further refine the initial version of our manuscript.

Open Access This article is distributed under the terms of the Creative Commons Attribution 4.0 International License (http://creativeco mmons.org/licenses/by/4.0/), which permits unrestricted use, distribution, and reproduction in any medium, provided you give appropriate credit to the original author(s) and the source, provide a link to the Creative Commons license, and indicate if changes were made.

\section{References}

Achyuthan H, Nagasundaram M, Gourlan AT, Eastoe C, Ahmad SM, Padmakumari VM (2014) Mid-Holocene Indian summer monsoon variability off the Andaman Islands, Bay of Bengal. Quat Intern 349:232-244

Ahmad SM, Anil Babu G, Padmakumari VM, Dayal AM, Sukhija BS, Nagabhushanam P (2005) Sr, Nd isotopic evidence of terrigenous flux variations in the Bay of Bengal: implications of monsoons during the last $\sim 34,000$ years. Geophys Res Lett $32: 1-4$

Ali S, Hathorne EC, Frank M, Gebregiorgis D, Stattegger K, Stumpf R, Kutterolf S, Johnson JE, Giosan L (2015) South Asian monsoon history over the past $60 \mathrm{kyr}$ recorded by radiogenic isotopes and clay mineral assemblages in the Andaman Sea. Geochem Geophys Geosys. https://doi.org/10.1002/2014gc005586

Allen R, Najman Y, Carter A, Barfod D, Bickle MJ, Chapman HJ, Garzanti E, Vezzoli G, Ando S, Parrish RR (2008) Provenance of the Tertiary sedimentary rocks of the Indo-Burman ranges, Burma (Myanmar): Burman arc or Himalayan derived? J Geol Soc 165:1045-1057

Amakawa H, Nozaki Y (1998) Nd isotopic variations of surface seawaters from the eastern Indian Ocean and its adjacent oceanic regions. Min Mag 62A:47-48

Amakawa H, Alibo DS, Nozaki Y (2000) Nd isotopic composition and REE pattern in the surface waters of the eastern Indian Ocean and its adjacent seas. Geochim Cosmochim Acta 64:1715-1727

Awasthi N, Ray JS, Singh AK, Band ST, Rai V (2014) Provenance of the late Quaternary sediments in the Andaman Sea: implications for monsoon variability and ocean circulation. Geochem Geophys Geosys 15:3890-3906

Barnett TP, Dumenil L, Schlese U, Roeckner E (1988) The effect of Eurasian snow cover on global climate. Science 239:504-507

Battisti DS, Ding Q, Roe GH (2014) Coherent pan-Asian climatic and isotopic response to orbital forcing of tropical insolation. J Geophy Res 119:11997-12020

Bayon G, German CR, Boella RM, Milton JA, Taylor RN, Nesbitt RW (2002) Sr and Nd isotope analyses in paleoceanography: the separation of both detrital and $\mathrm{Fe}-\mathrm{Mn}$ fractions from marine sediments by sequential leaching. Chem Geol 187:179-199

Bender F (1983) Geology of Burma. Gebrüder Borntraeger, Berlin

Berkelhammer M, Sinha A, Stott LD, Cheng H, Pausata FSR, Yoshimura K (2012) An abrupt shift in the Indian monsoon 4000 years ago. In: Giosan L, Fuller DQ, Nicoll K, Flad RK, Clift PD (eds) Climates, landscapes, and civilizations. Geophysical Monograph series 198. American Geophysical Union, Washington, DC, pp 75-87

Blaser P, Lippold J, Gutjahr M, Frank N, Link JM, Frank M (2016) Extracting foraminiferal seawater $\mathrm{Nd}$ isotope signatures from bulk deep-sea sediment by chemical leaching. Chem Geol 439:189-204

Borg LE, Banner JL (1996) Neodymium and strontium isotopic constraints on soil sources in Barbados, West Indies. Geochim Cosmochim Acta 60:4193-4206

Braun J, Voisin C, Gourlan AT, Chauvel C (2015) Erosional response of an actively uplifting mountain belt to cyclic rainfall variations. Earth Surf Dynam 3:1-14

Buffle J, Van Leeuwen HP (1992) Environmental particles: 1. In: environmental analytical and physical chemistry series. Lewis Publishers, London

Burton KW, Vance D (2000) Glacial-interglacial variations in the neodymium isotope composition of seawater in the Bay of Bengal recorded by planktonic foraminifera. Earth Planet Sci Lett 176:425-441

Cane M (2010) Climate: a moist model monsoon. Nature 463:163-164 
Chapman H, Bickle M, Thaw SH, Thiam HN (2015) Chemical fluxes from time series sampling of the Irrawaddy and Salween rivers, Myanmar. Chem Geol 401:15-27

Chauvel C, Blichert-Toft J (2001) A hafnium isotope and trace element perspective on melting of the depleted mantle. Earth Planet Sci Lett 190:137-151

Chen F, Li XH, Wang XL, Li QL, Siebel W (2007) Zircon age and NdHf isotopic composition of the Yunnan Tethyan belt, southwestern China. Int J Earth Sci 96:1179-1194

Clift PD, Carter A, Giosan L, Durcan J, Duller GAT, Macklin MG, Alizai A, Tabrez AR, Danish M, Laningham SV, Fuller DQ (2012) U-Pb zircon dating evidence for a Pleistocene Sarasvati River and capture of the Yamuna River. Geology 40:211-214

Cogez A, Allègre CJ, Meynadier L, Lewin E (2013) A statistical approach to the $\mathrm{Nd}$ isotopes distributions in the oceans. Mineral Mag. https://doi.org/10.1180/minmag.2013.077.5.3

Colin C, Turpin L, Bertauz J, Despraries A, Kissel C (1999) Erosional history of the Himalayas and Burman ranges during the last two glacial-interglacial cycles. Earth Planet Sci Lett 171:647-660

Contreras-Rosales LA, Jennerjahn T, Tharammal T, Meyer V, Lückge A, Paul A, Schefuß E (2014) Evolution of the Indian summer monsoon and terrestrial vegetation in the Bengal region during the past $18 \mathrm{ka}$. Quat Sci Rev 102:133-148

Dixit Y, Hodell DA, Petrie CA (2014) Abrupt weakening of the summer monsoon in northwest India 4100 years ago. Geology 42:339-342

Dutt S, Gupta AK, Clemens SC, Cheng H, Singh RK, Kathayat G, Edwards RL (2015) Abrupt changes in Indian summer monsoon strength during 33,800 to 5500 years BP. Geophys Res Lett. https ://doi.org/10.1002/2015gl064015

Dutta K, Bhushan R, Somayajulu BLK (2001) $\Delta$ R Correction values for the northern Indian Ocean. Radiocarbon 43:483-488

Dykoski CA, Edwards RL, Cheng H, Yuan D, Cai Y, Zhang M, Lin Y, Qing J, An ZS, Revenaugh J (2005) A high-resolution, absolutedated Holocene and deglacial Asian monsoon record from Dongge Cave, China. Earth Planet Sci Lett 233:71-86

Fleitmann D, Burns SJ, Mudelsee M, Neff U, Kramers J, Mangini A, Matter A (2003) Holocene forcing of the Indian monsoon recorded in a stalagmite from southern Oman. Science. https:// doi.org/10.1126/science. 1083130

Fleitmann D, Burns SJ, Mangini A, Mudelsee M, Kramers J, Villa I, Neff U, Al-Subbary AA, Buettner A, Hippler D, Mattera A (2007) Holocene ITCZ and Indian monsoon dynamics recorded in stalagmites from Oman and Yemen (Socotra). Quat Sci Rev 26:170-188

Frank M (2002) Radiogenic isotopes: tracers of past ocean circulation and erosional input. Rev Geophys. https://doi.org/10.1029/2000r g000094

Gaillardet J, Viers J, Dupré B (2014) Trace elements in River Waters (Chap. 7.7). In: Turekian KK, Holland HD (eds) Treatise on geochemistry, 2nd edn. Elsevier, Oxford, pp 195-235

Goldstein SJ, Jacobsen SB (1987) The Nd and Sr isotopic systematics of river-water dissolved material: implications for the sources of $\mathrm{Nd}$ and $\mathrm{Sr}$ in seawater. Chem Geol 66:245-272

Gourlan AT, Meynadier L, Allegre CJ (2008) Tectonically driven changes in the Indian Ocean circulation over the last $25 \mathrm{Ma}$ : neodymium isotope evidence. Earth Planet Sci Lett 26:353-364

Gourlan AT, Meynadier L, Allègre CJ, Tapponnier P, Birck JL, Joron JL (2010) Northern Hemisphere climate control of the Bengali rivers discharge during the past 4 Ma. Quat Sci Rev 29:2484-2498

Gutjahr M, Frank M, Stirlinga CH, Klemm V, van de Flierdt T, Halliday AN (2007) Reliable extraction of a deepwater trace metal isotope signal from FeMn oxyhydroxide coatings of marine sediments. Chem Geol 242:351-370

Hasan Z, Akhter S, Kabir A (2014) Analysis of rainfall trends in southeast Bangladesh. J Environ 3:51-56
Hein CJ, Galy V, Galy A, France-Lanord C, Kudrass H, Schwenk T (2017) Post-glacial climate forcing of surface processes in the Ganges-Brahmaputra river basin and implications for carbon sequestration. Earth Planet Sci Lett 478:89-101

Huck CE, van de Flierdt T, Jimenez-Espejo FJ, Bohaty SM, Röhl U, Hammond SJ (2016) Robustness of fossil fish teeth for seawater neodymium isotope reconstructions under variable redox conditions in an ancient shallow marine setting. Geochem Geophys Geosys. https://doi.org/10.1002/2015gc006218

Jacobsen SB, Wasserburg GJ (1980) Sm-Nd isotopic evolution of chondrites. Earth Planet Sci Lett 50:139-155

Jeandel C (1993) Concentration and isotopic composition of $\mathrm{Nd}$ in the southern Atlantic Ocean. Earth Planet Sci Lett 117:581-591

Jeandel C, Oelkers EH (2015) The influence of terrigenous particulate material dissolution on ocean chemistry and global element cycles. Chem Geol 395:50-66

Joussain R, Liu ZF, Colin C, Duchamp-Alphonse S, Yu ZJ, Moréno E, Fournier L, Zaragosi S, Dapoigny A, Meynadier L, Bassinot F (2017) Link between Indian monsoon rainfall and physical erosion in the Himalayan system during the Holocene. Geochem Geophys Geosyst 18:3452-3469

Laskar J, Robutel P, Joutel F, Gastineau M, Correia ACM, Levrad B (2004) A long-term numerical solution for the insolation quantities of the earth. Astrono Astrophy 428:261-285

Laskar AH, Yadava MG, Ramesh R, Polyak VJ, Asmerom Y (2013) A 4 kyr stalagmite oxygen isotopic record of the past Indian summer monsoon in the Andaman Islands. Geochem Geophys Geosyst 14:3555-3566

Licht A, France-Lanord C, Reisberg L, Fontaine C, Soe AN, Jaeger JJ (2013) A palaeo Tibet-Myanmar connection? Reconstructing the Late Eocene drainage system of central Myanmar using a multiproxy approach. J Geol Soc 170:929-939

Lupker M, France-Lanord C, Galy V, Lave J, Kudrass H (2013) Increasing chemical weathering in the Himalayan system since the Last Glacial Maximum. Earth Planet Sci Lett 365:243-252

Martin EE, Blair SW, Kamenov GD, Scher HD, Bourbon E, Basak C, Newkirk DN (2010) Extraction of Nd isotopes from bulk deep sea sediments for paleoceanographic studies on Cenozoic time scales. Chem Geol 269:414-431

Milliman JD, Farnsworth KL (2011) River discharge to the coastal ocean: a global synthesis. Cambridge University Press, Cambridge

Milliman JS, Meade RH (1983) World-wide delivery of river sediment to the oceans. J Geology 91:1-21

Milliman JD, Syvitski JPM (1992) Geomorphic/tectonic control of sediment discharge to the ocean: the importance of small mountainous rivers. J Geology 100:525-544

Miriyala P, Sukumaran NP, Nath BN, Ramamurty PB, Sijinkumar AV, Vijayagopal B, Ramaswamy V, Sebastian T (2017) Increased chemical weathering during the deglacial to mid-Holocene summer monsoon intensification. Sci Rep. https://doi.org/10.1038/ srep44310

Murata F, Terao T, Hayashi T, Asada H, Matsumoto J (2008) Relationship between the atmospheric conditions at Dhaka, Bangladesh, and rainfall at Cherrapunjee, India. Nat Hazards 44:399-410

Naqvi WA, Charles CD, Fairbanks RG (1994) Carbon and oxygen isotopic records of benthic foraminifera from the northeast Indian Ocean: implications on glacial-interglacial atmospheric $\mathrm{CO}_{2}$ changes. Earth Planet Sci Lett 121:99-110

Olivier N, Boyet M (2006) Rare earth and trace elements of microbialites in upper Jurassic coral- and sponge-microbialite reefs. Chem Geol 230:105-123

Piepgras DJ, Wasserburg GJ, Dasch EG (1979) The isotopic composition of Nd in different ocean masses. Earth Planet Sci Lett 45:223-236

Ramaswamy V, Rao PS, Rao KH, Thwin S, Rao NS, Raiker V (2004) Tidal influence on suspended sediment distribution and dispersal 
in the northern Andaman Sea and Gulf of Martaban. Mar Geol 208:33-42

Rashid H, Flower BP, Poore RZ, Quinn TM (2007) A 25 ka Indian Ocean monsoon variability record from the Andaman Sea. Quat Sci Rev 26:2586-2597

Rashid H, England E, Thompson LG, Polyak L (2011) Late glacial to Holocene Indian summer monsoon variability based upon sediment records taken from the Bay of Bengal. Terr Atmos Ocean Sci 22:215-228

Rashid H, Best K, Otieno FO, Shum CK (2013) Analysis of paleoclimatic records for understanding the tropical hydrologic cycle in abrupt climate change. Climate Vulnerability 5:127-139

Ray D, Rajan S, Ravindra R, Jana A (2011) Microtextural and mineral chemical analyses of andesite-dacite from Barren and Narcondam Islands: evidences for magma mixing and petrological implications. J Earth Syst Sci 120:145-155

Rempfer J, Stocker TF, Joos F, Dutay JC, Siddall M (2011) Modelling $\mathrm{Nd}$-isotopes with a coarse resolution ocean circulation model: sensitivities to model parameters and source/sink distributions. Geochim Cosmochim Acta 75:5927-5950

Rempfer J, Stocker TF, Joos F, Dutay JC (2012) Sensitivity of Nd isotopic composition in seawater to changes in $\mathrm{Nd}$ sources and paleoceanographic implications. J Geophy Res. https://doi. org/10.1029/2012jc008161

Robinson RAJ, Bird MI, Oo NW, Hoey TB, Aye MM, Higgitt DL, Lu XX, Swe A, Tun T, Win SL (2007) The Irrawaddy River sediment flux to the Indian Ocean: the original nineteenth-century data revisited. J Geology 115:629-640

Robinson RAJ, Brezina CA, Parrish RR, Horstwood MSA, Oo NW, Bird MI, Thein M, Walters AS, Oliver GJH, Zaw K (2014) Large rivers and orogens: the evolution of the Yarlung TsangpoIrrawaddy system and the eastern Himalayan syntaxis. Gondwana Res 26:112-121

Rousseau TC, Sonke JE, Chmeleff J, van Beek P, Souhaut M, Boaventura G, Seyler P, Jeandel C (2015) Rapid neodymium release to marine waters from lithogenic sediments in the Amazon estuary. Nat Commun 6:7592. https://doi.org/10.1038/ncomm s8592

Sebastian T, Natha BN, Venkateshwarlu M, Miriyala P, Prakash A, Linsya P, Kocherla M, Kazip A, Sijinkumar AV (2019) Impact of the Indian summer monsoon variability on the source area weathering in the Indo-Burman ranges during the last $21 \mathrm{kyr}$ - a sediment record from the Andaman Sea. Palaeogeo Palaeocli Palaeoeco 516:22-34

Sen Roy N, Kaur S (2000) Climatology of monsoon rains of Myanmar (Burma). Int J Climato 20:913-928

Shakun JD, Burns SJ, Fleitmann D, Kramers J, Matter A, Al-Subary A (2007) A high-resolution, absolute-dated deglacial speleothem record of Indian Ocean climate from Socotra Island. Yemen Earth Planet Sci Lett 259:442-456

Singh SP, Singh SK, Goswami V, Bhushan R, Rai VK (2012) Spatial distribution of dissolved neodymium and $\varepsilon \mathrm{Nd}$ in the Bay of Bengal: role of particulate matter and mixing of water masses. Geochim Cosmochim Acta 94:38-56

Sinha A, Cannariato K, Stott LD, Li HC, You CF, Cheng H, Edwards RL, Singh IB (2005) Variability of southwest Indian summer monsoon precipitation during the Bølling-Allerød. Geology 33:813-816

Socquet A, Pubellier M (2005) Cenozoic deformation in western Yunnan (China-Myanmar border). J Asian Earth Sci 24:495-515

Stoll HM, Vance D, Arevalos A (2007) Records of the Nd isotope composition of seawater from the Bay of Bengal: implications for the impact of Northern Hemisphere cooling on ITCZ movement. Earth Planet Sci Lett 255:213-228

Stuiver M, Reimer PJ, Reimer RW (2019) CALIB 7.1 [WWW program]. http://calib.org. Accessed 25 Apr 2019

Stumm W (1993) Aquatic colloids as chemical reactants: surface structure and reactivity. Colloids Surf A73:1-18

Tachikawa K, Arsouze T, Bayon G, Borye A, Colin C, Dutay JC, Frank N, Giraud X, Gourlan AT, Jeandel C, Lacan F, Meynadier L, Montagna P, Piotrowski AM, Plancherel Y, Pucéat E, Roy-Barman M, Waelbroeck C (2017) The large-scale evolution of neodymium isotopic composition in the global modern and Holocene ocean revealed from seawater and archive data. Chem Geol 457:131-148

Tripathy GR, Singh SK, Bhushan R, Ramaswamy V (2011) Sr-Nd isotope composition of the Bay of Bengal sediments: impact of climate on erosion in the Himalaya. Geochem J 45:175-186

Wang YJ, Cheng H, Edwards RL, An ZS, Wu JY, Shen CC, Dorale JA (2001) A high-resolution absolute-dated late Pleistocene monsoon record from Hulu Cave. China Sci 294:2345-2348

Webster PJ, Magana VO, Palmer TN, Shukla J, Tomas RA, Yanai M, Yahunari T (1998) Monsoons: processes, predictability, and the prospects for prediction. J Geophy Res. 103:14451-14510

Wilson DJ, Piotrowski AM, Galy A, Clegg JA (2013) Reactivity of neodymium carriers in deep-sea sediments: implications for boundary exchange and paleoceanography. Geochim Cosmochim Acta 109:197-221

Yadava MG, Ramesh R (2005) Monsoon reconstruction from radiocarbon dated tropical Indian speleothems. The Holocene. https:// doi.org/10.1191/0959683605h1783rp

Yu Z, Colin C, Meynadier L, Douville E, Dapoigny A, Reverdin G, Wu Q, Wan S, Song L, Xu Z, Bassinot F (2017) Seasonal variations in dissolved neodymium isotope composition in the Bay of Bengal. Earth Planet Sci Lett 479:310-321 